\title{
Prevalence of Violence Tendency in Adolescents*
}

\author{
Özlem HASKAN AVCI**
}

Received: 27 May 2013

\author{
İbrahim YILDIRIM***
}

Accepted: 08 April 2014

\begin{abstract}
The aim of this study is to analyze the extensiveness of violence tendency to depending on individual and family factors in adolescents. For this purpose, information has been collected from 899 high school students educated in state schools located in Adana province. Violence Tendency Scale (VTS) developed by Haskan and Yildirım (2012) has been used in order to determine the violence tendency levels of the students. The prevalence of students' tendency has been tested with chi-square. When analyzed in terms of individual characteristics, violence tendency has been found more extensive in boys rather than girls, and more extensive in the students watching violence and heroic movies. When it is analyzed in terms of family factors, violence tendency has been found to be more spread with the students experiencing violence at home, and having families using alcohol compared to the ones experiencing neither violence nor alcohol cases. Moreover, students whose fathers work and earn money display more tendency to violence than the ones whose fathers doesn't make money by working. Besides, students having family members in prison have been understood to be more tend to violence.
\end{abstract}

Keywords: adolescence, violence tendency, violence tendency scale

\section{Extended Abstract}

The increasing acts of violence in our country reached a disturbing level in the society. The fact of violence can be encountered more often during the adolescence period compared to the other periods of development.

Purpose and Significance: The present study aims to determine whether the frequency of tendency of violence in teenagers change significantly depending on the personal and familial characteristics.

Methods: The present study consists of 899 high school students. The Violence Tendency Scale (VTS) (Haskan \& Y1ldırım, 2012) was used to measure the violence tendencies of students. The Personal Information Form (PIF) developed by the researcher to collect data on the demographical characteristics of students and including the personal and familial variables. The questions in the PIF were regarded as the independent variables of the study. The students have been classified as the students with "high tendency to violence" and the ones with "no tendency to violence", through the use of scores obtained from VTS, (below-above $27 \%$ groups). According to the personal and familial variables discussed in the present study, the frequency of violent

\footnotetext{
The manuscript is part of a dissertation named "Violence Tendency, Social Support and Loneliness in Adolescents", Hacettepe University Institute of Social Science.

** Corresponding Author: Assist. Prof. Dr., Hacettepe University, Ankara, Turkey, haskan@ hacettepe.edu.tr

***Prof. Dr., Hacettepe University, Ankara, Turkey, iyil@ hacettepe.edu.tr
} 
acts towards students was tested using the chi-square test. The margin of error was taken .05 maximum.

Results: Accordingly, when the frequency of tendency for violence in terms of gender is analyzed, it is observed that $32 \%$ of the teenagers who have a tendency for violence $(\mathrm{n}=94)$ are female, while $76 \%(\mathrm{n}=165)$ are male in terms of personal characteristics $\left(\mathrm{X}^{2}=96.964 ; \mathrm{p}<.001\right)$. In other words, the frequency of tendency for violence in male students was found to be higher. Accordingly, when the frequency of tendency for violence in terms of watching TV series is analyzed, it is observed that $48.2 \%$ of the teenagers who have a tendency for violence $(n=158)$ watch TV series, while $54.9 \%$ $(n=101)$ do now watch TV series $\left(X^{2}=2.133 ; p>.05\right)$. Accordingly, when the frequency of tendency for violence in terms of watching quiz shows is analyzed, it is observed that $46.3 \%(n=25)$ of the teenagers who have a tendency for violence watch quiz shows, while $51.1 \%(n=234)$ do now watch quiz shows $\left(X^{2}=.458 ; p>.05\right)$. Accordingly, when the frequency of tendency for violence in terms of watching violent movies is analyzed, it is observed that $88.9 \%(n=56)$ of the teenagers who have a tendency for violence watch violent movies, while $45.2 \%(n=203)$ do now watch violent movies $\left(X^{2}=46.989\right.$; $\mathrm{p}<.001)$. Accordingly, when the frequency of tendency for violence in terms of watching heroic movies is analyzed, it is observed that $66 \%(n=35)$ of the teenagers who have a tendency for violence watch heroic movies, while $48.8 \%(n=224)$ do now watch heroic movies $\left(\mathrm{X}^{2}=10.826 ; \mathrm{p}<.05\right)$.

In terms of familial characteristics, when the prevalence of tendency for violence depending on whether the mother does an income-generating job was analyzed, it was found out that the mothers of $51.5 \%(\mathrm{n}=70)$ of the teenagers who have a high tendency of violence did an income-generating job, while the mothers of $50.2 \%(n=189)$ of them did not do an income-generating job $\left(\mathrm{X}^{2}=.528 ; \mathrm{p}>.05\right)$. In terms of familial characteristics, when the prevalence of tendency for violence depending on whether the father does an income-generating job was analyzed, it was found out that the fathers of $52.5 \%(n=229)$ of the teenagers who have a high tendency of violence did an incomegenerating job, while the fathers of $39.5 \%(n=30)$ of them did not do an incomegenerating job $\left(\mathrm{X}^{2}=6.319 ; \mathrm{p}<.05\right)$. When the prevalence of tendency for violence depending on whether the mother does an income-generating job was analyzed, it was found out that the mothers of $51.5 \%(\mathrm{n}=70)$ of the teenagers who have a high tendency of violence did an income-generating job, while the mothers of $50.2 \%(n=189)$ of them did not do an income-generating job $\left(\mathrm{X}^{2}=.528 ; \mathrm{p}>.05\right)$. In terms of familial characteristics, when the prevalence of tendency for violence depending on whether the father does an income-generating job was analyzed, it was found out that the fathers of $52.5 \%(n=229)$ of the teenagers who have a high tendency of violence did an incomegenerating job, while the fathers of $39.5 \%(n=30)$ of them did not do an incomegenerating job $\left(\mathrm{X}^{2}=6.319 ; \mathrm{p}<.05\right)$. 
When the prevalence of tendency for violence depending on whether the family members perpetrate violence against each other was analyzed, it was found out that the family members of $71 \%(n=27)$ of the teenagers who have a high tendency of violence perpetrate violence against each other, while $49 \%$ of them do not perpetrate violence against each other $\left(X^{2}=10.917 ; p<.05\right)$. It was found out that the $79.7 \%(n=51)$ of the teenagers who have a high tendency of violence was perpetrated violence by a nonfamily member, while $46.4 \%(n=208)$ of them were not perpetrated violence by a nonfamily member $\left(X^{2}=25.909 ; p<.001\right)$. It was found out that the family members of $73.7 \%(n=28)$ of the teenagers who have a high tendency of violence perpetrated violence against the teenager, while $48.7 \%(n=231)$ of them did not perpetrate violence against the teenager $\left(X^{2}=9.269 ; \mathrm{p}<.01\right)$.

When the prevalence of tendency for violence depending on whether the family members use alcohol was analyzed, it was found out that the family members of $63.1 \%$ $(n=70)$ of the teenagers who have a high tendency of violence use alcohol, while $47.1 \%$ $(n=189)$ of them did not use alcohol $\left(X^{2}=9.238 ; p<.01\right)$. When the prevalence of tendency for violence depending on whether any of the family members have been a prisoner was analyzed, it was found out that the $78.8 \%(n=26)$ of the teenagers who have a high tendency of violence had somebody who was/has been a prisoner in the family, while $48.6 \%(n=233)$ did not have such a person $\left(X^{2}=10.917 ; p<.01\right)$.

Discussion and Conclusions: In order to be able to decrease the violence tendency, it is assumed essential that some empirical studies should be made in order to decrease the violence tendency; the families and teachers should be educated about this issue and cooperated, and some several studies should be conducted. 


\section{Ergenlerde Şiddet Eğiliminin Görülme Sıklığı*}

\author{
Özlem HASKAN AVCI**
}

\author{
İbrahim YILDIRIM***
}

Makale Gönderme Tarihi: 27 Mayıs 2013

Makale Kabul Tarihi: 08 Nisan 2014

ÖZET: Bu çalışmanın amacı, bireysel ve ailesel değişkenlere göre ergenlerde şiddet eğiliminin görülme sıklığının incelenmesidir. $\mathrm{Bu}$ amaçla Adana'ya bağlı devlet okullarında öğrenim gören 899 lise öğrencisinden bilgi toplanmıştır. Bilgi toplama aracı olarak Haskan ve Yıldırım (2012) tarafından geliştirilen Şiddet Eğilimi Ölçeği (ŞEÖ); ve araştırmacı tarafından oluşturulan Kişisel Bilgi Formu kullanılmıştır. Bireysel ve ailesel değişkenlere göre ergenlerde şiddet eğiliminin görülme sıklığı ki-kare ile test edilmiştir. Buna göre, bireysel nitelikler bakımından incelendiğinde, şiddet eğilimi, erkek ergenler arasında, akademik başarısı düşük olan, şiddet filmleri ve kahramanlık filmleri izleyen ergenler arasında diğer gruplara göre daha fazla görülmektedir. Ailesel nitelikler bakımından incelendiğinde ise, ailesinde şiddet uygulanan, ailede ve aile dişında şiddete maruz kalan, ailesinde cezaevinde kalmış/ kalmakta olanların ve alkol kullananların olduğu ergenler arasında şiddet eğilimi daha sık görülmektedir. Babası gelir getiren bir işte çalışan ergenler arasında şiddet eğilimi daha sık görülmekteyken; annesi gelir getiren bir işte çalışan ve çalışmayan ergenler arasında fark manidar bulunmamıştır.

Anahtar sözcükler: ergenlik, şiddet eğilimi, şiddet eğilimi ölçeği

\section{Giriş}

Ülkemizde her geçen gün artan şiddet olayları tedirginlik yaratan boyutlara ulaşmıştır. Günümüzde şiddet ne yazık ki tüm yaşam alanlarına yayılmış durumdadır. Pek çok insan sokakta, trafikte, işyerlerinde hatta kendi evlerinde şiddete maruz kalmakta; insanların bir kriz durumunda birbirine nasıl davranmaları gerektiğini kestiremedikleri güvensiz bir iletişim ortamı hâkim hale gelmektedir. Basit bir anlaşmazlık yüzünden ciddi boyutta şiddete maruz kalan hatta öldürülen insanların sayısındaki artış korkutucudur. Son yıllarda, şiddet içeren haberler farklılaşmakla birlikte, ekrana yansıyan şiddet olayları daha da çarpıcı hale gelmektedir. Ülkemizde bir dönem eğitimciler tarafindan başvurulan şiddet konuşulurken; bir dönem eğitimcilere, öğretmenlere yönelik şiddet, başka bir dönem doktorlara yönelik, kadına yönelik şiddet konuşulur hale gelmiştir. Şiddetin azalmayıp sadece görünüm değiştirdiği anlaşılmaktadır; yani şiddetin uygulayıcıları ve kurbanlar değişmekte; ancak şiddet sahneleri varlığını korumaktadır. Bu durum şiddeti azaltmaya yönelik girişimlerin yeterli olmadığını düşündürmektedir. Şiddetin azaltılmasına yönelik daha fazla araştırmaya ihtiyaç duyulduğu anlaşılmaktadır.

Şiddetle karşılaşmanın en tehlikeli hale geldiği kurum, eğitim ve kültürleme ortamı olması bakımından okullardır. Maalesef okullarda da şiddet artmaktadır. Milli Eğitim Bakanlığı'nın "Eğitim Ortamlarında Şiddetin Önlenmesi ve Azaltılması Strateji ve Eylem Planı (2006- 2011+)" nın oluşturulma gerekçeleri arasında, Türkiye'nin çeşitli illerinde gerçekleştirilen araştırmalarda, eğitim ortamlarında yaşanan şiddetin göz ardı edilemeyecek boyutlarda olduğu yer almaktadır (TBMM Araştırma Komisyon Raporu, 2007). Dünya genelinde de benzer bir durum söz konusudur. Avrupa Konseyi'nin

\footnotetext{
" Bu makale Hacettepe Üniversitesi Sosyal Bilimler Enstitüsü, "Ergenlerde Şiddet Eğilimi, Yalnızlık ve Sosyal Destek" adlı yüksek lisans tezinin bir bölümüdür.

** Sorumlu Yazar: Yard. Doç. Dr., Hacettepe Üniversitesi, Ankara, haskan@ hacettepe.edu.tr

*** Prof. Dr., Hacettepe Üniversitesi, Ankara, iyil@ hacettepe.edu.tr
} 
Okullarda Şiddetin Önlenmesi ve Şiddetle Mücadele İçin Yerel Ortaklıklar Konferansı Sonuç Bildirgesi'ne göre, okulda şiddet yeni bir olgu değildir; ancak son yıllarda özelikle okulların kendilerini genelde toplumu, özelde okulların içinde yer aldığı yerel toplumları etkileyen zorluk ve gerilimlerden uzak tutamamaları nedeniyle, şiddetin içeriğinin kayda değer bir biçimde arttığı görülmektedir (Gittins, 2005). Güney Afrika Irk İlişkileri Enstitüsü'nün (South African Institute of Race Relations-SAIRR) raporuna göre, 12-22 yaş arası gençler yetişkinlere göre iki kat daha fazla şiddet kurbanı olmakta (Blaser, 2008); hatta Güney Afrika'da gençler için okul, hırsızlık, saldırı ve cinsel tacizin en yoğun yaşandığı yer olarak görülmektedir (Burton, 2008).

Şiddet vakaları ve çeşitli saldırıların yaşanabileceğine dair korkular okul içi atmosferi ve duygusal, sosyal ve akademik gelişimi de olumsuz etkilemektedir (Thomas \& Smith, 2004). ABD Okulda Şiddetin Kaynakları Merkezi (USA School Violence Resource Center) raporunda (2002), okulda şiddetle ilgili risk faktörleri içinde, suç işlemeye eğilimli arkadaşlık ilişkileri, sapkın bir akran grubuna sahip olmak, bireysel saldırganlık, madde kullanımı, akademik başarısızlık, sosyal izolasyon ve sosyal reddedilmenin etkili olabileceği belirtilmektedir. Okulların sahip olduğu olumsuz şartlar, suç ve şiddetin oluşmasında etkin rol oynamaktadır. Okul ve sınıfların aşırı derecede büyük ve kalabalık olması, eğitim ortamına ilişkin yetersizlikler, öğrenci başarısının düşüklüğü, öğrencilerin okula ve derslere karşı ilgisizliği gibi olumsuz şartlar suç ve şiddet davranışlarının ortaya çıkmasına neden olabilmektedir (Fager \& Boss, 1998).

Elbette ergen şiddetinden söz edilirken, ailesel etkenler göz ardı edilemez. Çocuğun ailede sevgi ve destek görmüyor olması, evde şiddet olması, çocukları şiddete yönlendiren bazı ailesel etkenlerdir (Çuhadaroğlu, 2006; Özcebe, 2006). Öfkeli ve şiddet eğilimi yüksek olan ergenler, aile ortamlarını betimlemeleri istendiğinde, sağlıklı bir aile birliği olmayan, katı, çelişkili ve örgütlenmemiş bir aile ortamında büyüdüklerini belirtmişlerdir (İnanç, Bilgin \& Atıcı, 2005). Belirtilenlerin dışında, ailenin suça ve şiddete yönelik geçmişi, anne-babanın beklentilerinin yetersiz ya da düşük düzeyde olması, anne-babanın denetiminin yetersizliği, ailede ilaç ya da alkol kullanımı, çocukların istismarı ve ihmali de ailesel risk faktörleri arasında anılmaktadır (USA School Violence Resource Center, 2002). Unnever, Cullen \& Agnew (2006) yaptıkları çalışmada, "kötü" ebeveynliğin, bireylerin kendini kontrol mekanizmasının zayıf olmasına ve öfke ve şiddet eğilimiyle bağlantılı anti sosyal davranışlara yönelimde etkili olduğu görülmüştür. Ailede şiddete tanık olarak gelişen bireylerin yetişkin şiddet uygulayıcılarına dönüştükleri bulgusu yapılan çalışmalarda görülmektedir (Heitmeyer \& Hagan, 2005). Bu durum şiddetin sosyal kalıtım ile aktarıldığı iddiasını doğrular görünmektedir. Ayrıca şiddetin ortaya çıkmasında model almanın etkisini de gözler önüne sermektedir.

Dünya Sağlı Örgütü'nün açıklamalarına göre, toplumun sosyal yapısı, demografik yapı ve bunun değişimi, toplumdaki sosyoekonomik eşitsizlikler, çocuk ve aile politikaları, koruyucu sağlık hizmetlerinin varlığ ve etkinliği ve adalet sisteminin işleyişi gibi temel konular şiddetin görülme sıklığını 
etkilemektedir (Krug, Dahlberg, Mercy ve diğerleri, 2002). Adalet sistemine olan güvensizlik, ergenleri karşılaştıkları zorlu olaylarda kendi adaletini oluşturma ve uygulama olarak anılabilecek intikam ve zarar verme davranışlarına sürükleyebilmektedir. Özcebe'ye (2006) göre toplumda düşük sosyal statüde bulunan kesimlerde ve gelir eşitsizliği arttıkça gençler arasında şiddet artmaktadır. Gençler arasında çeteleşme ve madde kullanımı şiddeti beraberinde getiren riskli davranışlardır. Toplumdaki demografik yapının değişimi, gen nüfusun artması, eğitim ve iş istihdam olanaklarının yeterince sağlanamaması, göçler nedeniyle ortaya çıkan çarpık kentleşme gibi pek çok etmen gençleri olumsuz etkilemektedir. Gençlerin yaşama ve topluma bakış açıları değişmekte ve şiddet davranışları artmaktadır (Özcebe, 2006). Şiddetin süregelmesinde gözden kaçırılmaması gereken önemli bir neden de şiddetten para kazananların şiddeti desteklemesidir. Şiddet toplumsal olgularda çıkar dikkate alınmadan açıklanamaz; şiddet davranışlarının gerisinde de bir maliyet- yarar hesabı yatar. Şiddet işe yaradığı sürece kullanılır ve kullanılmaya devam eder (Gümüş, 2006). Silah sektörü, bilgisayar oyunları üreticileri, basın yayın haber üreticileri, reyting meraklıları, oyuncak üreticileri ve korunma- güvenlik aletleri üreticileri şiddetten para kazanmaktadır. ABD'de, göz yaşartıcı ve sersemletici spreylere, alarm sistemlerine y1lda 400 milyon dolar harcandığı saptanmıştır (Debarbieux, 2009).

Şiddetin artmasında medyanın etkilerine dair de sayısız araştırma söz konusudur. Atkinson ve Atkinson'a göre (2008) göre, medya, sıklıkla gösterilen şiddet görüntüleri ile şiddete eğilimli birey için, şiddete ilişkin yeni yöntemleri öğrenebileceği, en ucuz ve en kolay ulaşabileceği kaynaktır. Saldırganlık ve şiddet olgusu, gözlem ya da taklit yoluyla öğrenilebilir ve ne kadar pekiştirilirse meydana gelme olasılığı o kadar artar. Araştırmalar, çocukların anne babalarından ve öğretmenlerinden ziyade medya ile birlikte büyüdüklerinin altını çizmektedir. Çocukların eğitimi, adeta "elektronik dadılara" terk edilmiş durumdadır (İpek, 2007). Dünya Sağlık Örgütü'nün açıklamalarına göre medyada şiddete tanık olan çocuklar, kendileri şiddete maruz kalmasalar bile model alma yoluyla sorun çözme yolu olarak şiddeti öğrenebilmektedirler. Ayrıca bu tür davranışların sonuçlarına karşı duyarsızlaşma yoluyla şiddete eğilimli hale gelmektedirler. Bu kaynakları izleme süreleri arttıkça şiddet davranışı da artmaktadır (Krug ve diğerleri, 2002).

Şiddetle ilgili risk faktörleri oldukça geniş bir yelpazeye sahiptir. Şiddetle ilgili tüm risk faktörlerini bu çalışmanın çatısı içinde ele almak elbette mümkün değildir. Ancak şiddeti önleyebilmek için, şiddet eğilimi ile ilgili değişkenleri anlamaya çalışmakta fayda olacağı görülmektedir. Dolayısıyla, yapılan bu araştırmada şiddetle ilgili bazı bireysel ve ailesel değişkenleri ele almak ve şiddet eğiliminin bu değişkenlere göre ergenler arasında görülme sıklığını incelemek amaçlanmıştır.

\section{Araştırmanın Amacı}

$\mathrm{Bu}$ araştırmanın amacı ergenlerde şiddet eğiliminin görülme sıklığının ve şiddet eğiliminin ergenlerin bireysel ve ailesel niteliklerine göre manidar olarak değişip değişmediğinin belirlenmesidir. Buna bağlı olarak araştırmada aşağıdaki sorulara yanıtlar aranmıştır: 
1) Öğrencilerin bireysel niteliklerinden,

a) cinsiyet, b) not ortalaması, c) izlediği tv program türü

2) Öğrencilerin ailesel niteliklerinden,

a) annenin gelir sağlayıcı bir işte çalışıp çalışmaması, b) babanın gelir sağlayıcı çalışıp çalışmaması, c) aile bireylerinin birbirine şiddet uygulayıp uygulamaması, d) ailede ergenin kendisine şiddet uygulayan birinin bulunup bulunmaması, e) ergenin aile dışında birilerinden şiddet görüp görmemesi, f) ailede alkol kullanılıp kullanılmaması, g) ailede cezaevinde yatmış/yatmakta olan birinin olup olmaması

değişkenlerine göre ortaöğretim öğrencilerinde şiddet eğiliminin görülme sıklığg manidar olarak farklı mıdır" sorularına yanıtlar aranmıştır.

\section{Çalışma Grubu}

\section{Yöntem}

Araştırma gereği 2008-2009 öğretim yılında, Adana'nın merkez ilçeleri olan Çukurova ve Seyhan ve Yüreğir'de öğrenim görmekte olan öğrencilerden bilgi toplanmıştır. Bu amaçla, 10 farklı ortaöğretim okulunda öğrenim görmekte olan 899 öğrenciye ulaşılmıştır. Araştırmaya katılan öğrencilerin okul türlerine ve cinsiyete göre dağılımları Tablo 1'de verilmiştir.

Tablo 1

Öğrencilerin Öğrenim Gördükleri Okul Türüne ve Cinsiyete Göre Dă̆ılımı

\begin{tabular}{lllll}
\hline Okul Türü & K1z & Erkek & $\mathrm{n}$ & $\%$ \\
\hline Meslek Lisesi & 140 & 116 & 256 & 28.4 \\
Genel Lise & 190 & 146 & 336 & 36.9 \\
Anadolu Lisesi & 156 & 151 & 307 & 34.7 \\
\hline $\mathrm{n}$ & 486 & 413 & 899 & 100 \\
\hline$\%$
\end{tabular}

Tablodan da izlenebileceği gibi, araştırmaya katılan öğrencilerin \%28.4'ü meslek liselerinde, \%36.9'u genel liselerde, \%34.7'si anadolu liselerinde öğrenim görmektedir. Araştırmaya katılan kız öğrencilerin oranı \%54.1 iken, erkek öğrencilerin oranı \%45.9'dur. Ayrıca, araştırmaya katılan öğrencilerin \%26.6's1 9. sınıf, \%25.1'i 10. sınıf, \%28.6'sı 11. sınıf ve \%18.6'sı 12. sınıf öğrencilerinden oluşmaktadır.

\section{Veri Toplama Araçları}

$\mathrm{Bu}$ araştırma kapsamında, orta öğretim öğrencilerinin şiddet eğilimini ölçmek amacıyla, Şiddet Eğilimi Ölçeği (ŞEÖ) (Haskan \& Yıldırım, 2012) kullanılmıştır. Öğrencilerin demografik nitelikleri hakkında bilgi toplamak amacıyla araştırmacı tarafından geliştirilen ve bireysel ile ailesel değişkenleri içeren kişisel bilgi formu, ŞEÖ 
ile birlikte öğrencilere verilmiştir. Kişisel Bilgi Formu'nda yer alan sorular araştırmanın bağımsız değişkenleri olarak ele alınmıştır.

Şiddet eğilimi ölçeği. Ergenlerde şiddet eğilimini ölçmek amacıyla araştırmacı tarafından geliştirilmiş olan Şiddet Eğilimi Ölçeği (ŞEÖ), 1 tanesi tersine çevrilmiş (reverse) olmak üzere toplam 20 maddeden oluşmaktadır. Ölçek üçlü derecelendirmeli (3=her zaman, 2= bazen, 1=hiçbir zaman) olup; düz maddeler, olduğu gibi; tersine çevrilmiş madde ise tersinden puanlanmaktadır. ŞEÖ'den alınabilecek puan 20 ile 60 arasında değişmektedir. Yüksek puan bireyin şiddet eğiliminin yüksek olduğu anlamına gelmektedir. Hem bireysel hem grup halinde uygulanabilen ölçeğin cevaplandırılma süresi yaklaşık 15 dakikadır.

ŞEÖ’nün geçerlik çalışmaları doğrultusunda yapı geçerliği ve benzer ölçekler geçerliği incelenmiştir. ŞEÖ’ye ilişkin KMO katsayısı .898 ve Bartlett testi anlamlı çıkmıştır. Faktörlerin her bir değişken üzerindeki ortak faktör varyansının .45 ile .68 arasında değiştiği görülmüştür. ŞEÖ'de öz değeri 1'den büyük olan 4 faktör saptanmıştır. ŞEÖ, toplam varyansın \%55.45'ini açıklamaktadır. Birinci faktörün tek başına varyansın \%33'ünü açıkladığı ve maddelerin faktör yüklerinin birinci faktörde .411 ile .670 arasında değiştiği izlenmiştir. ŞEÖ’nün benzer ölçekler geçerliğini incelemek amacıyla Tuzgöl (2000) tarafindan geliştirilen Saldırganlık Ölçeği (SÖ) kullanılmıştır. Her iki ölçek, Adana'da bir ortaöğretim okulunda okuyan 92 öğrenciye uygulanmış; SÖ ile ŞEÖ arasında pozitif yönde ve manidar düzeyde .64'lük bir korelasyon saptanmıştır. ŞEÖ’nün güvenirliğine ilişkin bulgular ise şöyledir: ŞEÖ’nün Alpha güvenirlik katsayısı (Alpha=.87) olarak bulunmuştur. Ayrıca, ŞEÖ üç hafta ara ile 140 öğrenciye iki kez uygulanmış ve böylece test tekrar test güvenirlik katsayısı $\left(\mathrm{r}^{\mathrm{XX}}=.83\right.$ ) olarak hesaplanmıştır (Haskan \& Yıldırım, 2012).

Kişisel bilgi formu. Kişisel Bilgi Formu, araştırmacı tarafından geliştirilmiş olup iki bölümü içerecek şekilde düzenlenmiştir. Birinci bölümde cinsiyet, not ortalaması, izlenen tv programları gibi değişkenlere ilişkin sorulara yer verilmiştir. İkinci bölümde ise, ailesel değişkenler olan annenin gelir sağlayıcı bir işte çalışıp çalışmaması, babanın gelir sağlayıcı çalışıp çalışmaması, aile bireylerinin birbirine şiddet uygulayıp uygulamaması, ailede ergenin kendisine şiddet uygulayan birinin bulunup bulunmaması, ergenin aile dışında birilerinden şiddet görüp görmemesi, ailede alkol kullanılıp kullanılmaması, ailede cezaevinde yatmış/yatmakta olan birinin olup olmaması değişkenlerine ilişkin sorulara yer verilmiştir.

\section{Verilerin Analizi}

Öğrencilerin ŞEÖ'den aldıkları puanlar kullanılarak (alt-üst \%27'lik gruplar) öğrenciler "şiddet eğilimi olmayan" (20-29 puan) ve "yüksek şiddet eğilimi olan" (3760 puan) şeklinde iki gruba ayrılmıştır. Araştırmada ele alınan bireysel ve ailesel değişkenlere göre öğrencilerin şiddet eğiliminin görülme sıklı̆̆ edilmiştir. Araştırmada hata payı en fazla .05 olarak kabul edilmiştir. 


\section{Bulgular}

$\mathrm{Bu}$ bölümde ergenlerde şiddet eğiliminin, bireysel ve ailesel nitelikler açısından görülme sıklığına ilişkin bulgular sırasıyla ele alınmıştır.

\section{Ergenlerde Şiddet Eğiliminin Bireysel Nitelikler Açısından Görülme Sıklığı}

Bireysel nitelikler arasında, öğrencilerin cinsiyeti, not ortalamaları ve izledikleri tv program türleri ele alınmıştır. Bireysel nitelikler açısından şiddet eğiliminin görülme sıklığına ilişkin bulgular Tablo 2'de gösterilmiştir.

Tablo 2

Öğrencilerin Bireysel Niteliklerine Göre Şiddet Ĕ̆iliminin Görülme Sıklı̆̆ına İlişkin Bulgular

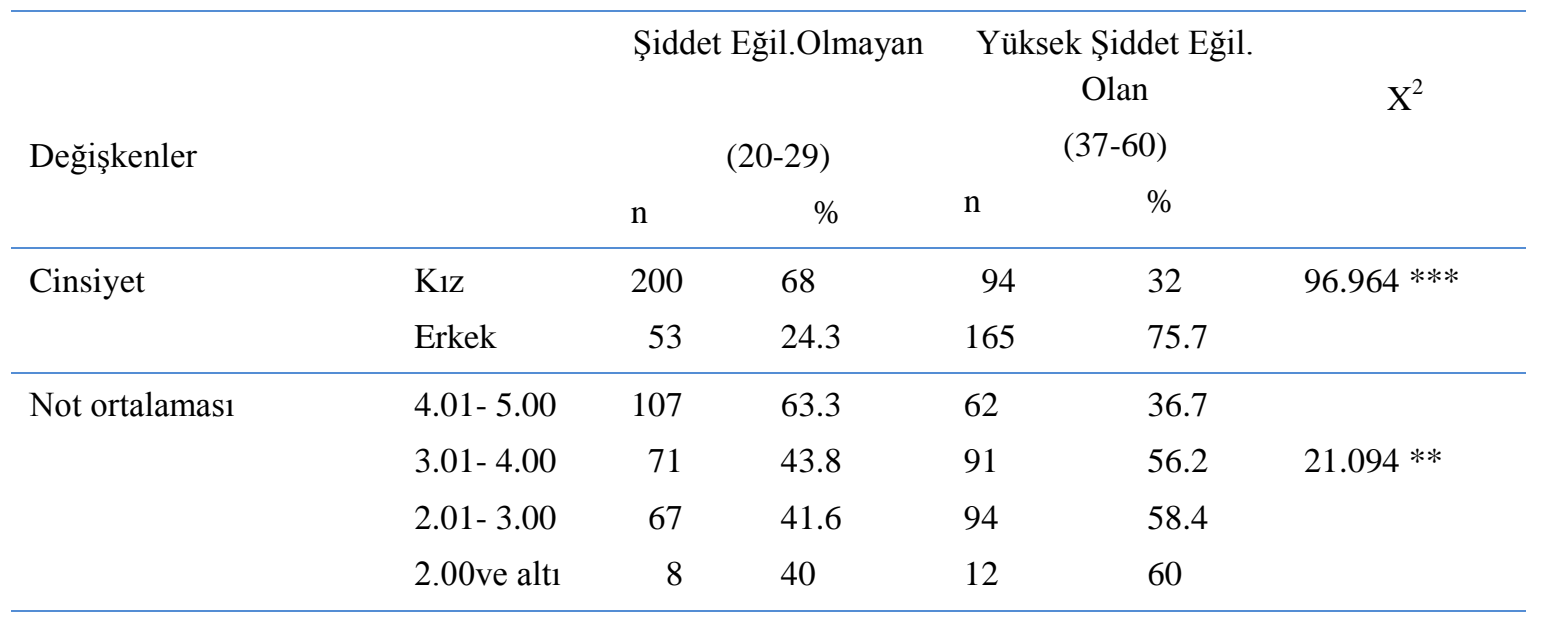

İzlediği program türü

Dizi filmler

\begin{tabular}{llrlrrr} 
& Evet & 170 & 51.8 & 158 & 48.2 & 2.133 \\
& Hayır & 83 & 45.1 & 101 & 54.9 & \\
\hline \multirow{2}{*}{ Yarışma } & Evet & 116 & 54.2 & 98 & 45.8 & \\
& Hayır & 137 & 46 & 161 & 54 & 49.20 \\
\hline \multirow{2}{*}{ Şiddet film. } & Evet & 7 & 11.1 & 56 & 88.9 & $46.989 * * *$ \\
& Hayır & 246 & 54.8 & 203 & 45.2 & \\
\hline \multirow{2}{*}{ Kahramanlık } & Evet & 18 & 34 & 35 & 66 & \\
& Hayır & 235 & 51.2 & 224 & 48.8 & $10.826 *$
\end{tabular}

$* \mathrm{p}<.05 \quad * * \mathrm{p}<.01 \quad * * * \mathrm{p}<.001$

Cinsiyete göre şiddet eğiliminin görülme sıklı̆̆ı incelendiğinde, yüksek şiddet eğilimi olan ergenlerin \% 32'sinin $(n=94)$ kı, \%76'sının $(n=165)$ erkek olduğu gözlenmektedir. Gruplara ilişkin gözlenen yüzdeler arasındaki fark manidar bulunmuştur $\left(X^{2}=96.964 ; \mathrm{p}<.001\right)$. Başka deyişle, erkek öğrenciler arasında şiddet eğiliminin görülme sıklığg daha yüksek çıkmıştır. 
Dizi film izlemeye göre şiddet eğiliminin görülme sıklı̆̆g incelendiğinde, yüksek şiddet eğilimi olan ergenlerin \% 48.2'sinin $(n=158)$ dizi film izlediği, \%54.9'unun $(n=101)$ dizi film izlemediği gözlenmektedir. Gruplara ilişkin gözlenen yüzdeler arasındaki fark manidar bulunmamıştır $\left(\mathrm{X}^{2}=2.133\right.$; $\left.\mathrm{p}>.05\right)$. Yarışma programı izlemeye göre şiddet eğiliminin görülme sıklı̆̆ı incelendiğinde, yüksek şiddet eğilimi olan ergenlerin \%46.3'ünün $(n=25)$ yarışma programı izlediği, \%51.1'inin $(n=234)$ yarışma programı izlemediği gözlenmektedir. Gruplara ilişkin gözlenen yüzdeler arasındaki fark manidar bulunmamıştır. $\left(X^{2}=.458 ; p>.05\right)$.

Şiddet filmleri izlemeye göre şiddet eğiliminin görülme sıklı̆̆ı incelendiğinde, yüksek şiddet eğilimi olan ergenlerin \%88.9'unun $(n=56)$ şiddet filmleri izlediği, \%45.2'sinin ( $\mathrm{n}=203)$ şiddet filmleri izlemediği gözlenmektedir. Gruplara ilişkin gözlenen yüzdeler arasındaki fark manidar bulunmuştur $\left(X^{2}=46.989 ; p<.001\right)$. Başka deyişle, sık ve düzenli olarak şiddet filmleri izleyen öğrenciler arasında şiddet eğiliminin görülme sıklığı daha yüksek çıkmıştır. Kahramanlık filmleri izlemeye göre şiddet eğiliminin görülme sıklığı incelendiğinde, yükssek şiddet eğilimi olan ergenlerin \%66'sının ( $\mathrm{n}=35)$ kahramanlık filmleri izlediği, \%48.8'inin ( $\mathrm{n}=224)$ kahramanlık filmi izlemediği gözlenmektedir. Gruplara ilişkin gözlenen yüzdeler arasındaki fark manidar bulunmuştur $\left(\mathrm{X}^{2}=10.826 ; \mathrm{p}<.05\right)$. Başka deyişle, sık ve düzenli olarak kahramanlık filmleri izleyen öğrenciler arasında şiddet eğiliminin görülme sıklığı daha yüksek çıkmıştır.

\section{Ergenlerde Şiddet Eğiliminin Ailesel Nitelikler Açısından Görülme Sıklığı}

Ergenlerde şiddet eğiliminin, ailesel nitelikler açısından görülme sıklığının incelenmesinde ki kare uygulanmıştır. Ailesel nitelikler arasında, anne ve babanın gelir sağlayıcı bir işte çalışıp çalışmaması, aile bireylerinin birbirlerine şiddet uygulayıp uygulamadıkları, ergene şiddet uygulayıp uygulamadığı, ergenin aile dışında şiddet uygulanıp uygulanmadığı, ailede alkol kullanan olup olmaması, ailede cezaevinde kalmış/ kalmakta olan birinin olup olmaması değişkenleri ele alınmıştır. Bireysel nitelikler açısından şiddet eğiliminin görülme sıklığına ilişkin bulgular Tablo 3'de gösterilmiştir. 
Tablo 3

Ailesel Niteliklerine Göre Ergenlerde Şiddet Ĕ̆iliminin Görülme Siklı̆̆ı

\begin{tabular}{|c|c|c|c|c|c|c|}
\hline \multirow[b]{2}{*}{ Değişkenler } & & \multicolumn{2}{|c|}{$\begin{array}{c}\text { Şiddet } \\
\text { Eğil.Olmayan } \\
(20-29)\end{array}$} & \multicolumn{2}{|c|}{$\begin{array}{c}\text { Yüksek Şiddet Eğil. } \\
\text { Olan } \\
(37-60)\end{array}$} & \multirow[t]{2}{*}{$X^{2}$} \\
\hline & & $\mathrm{n}$ & $\%$ & $\mathrm{n}$ & $\%$ & \\
\hline \multirow[t]{2}{*}{ Baba İş. } & Evet & 207 & 47.5 & 229 & 52.5 & \\
\hline & Hayır & 46 & 60.5 & 30 & 39.5 & $6.319 *$ \\
\hline \multirow{2}{*}{ Anne İş. } & Evet & 66 & 48.5 & 70 & 51.5 & \\
\hline & Hayır & 187 & 49.8 & 189 & 50.2 & .528 \\
\hline \multirow[t]{2}{*}{ Ailede Şiddet } & Evet & 11 & 29 & 27 & 71 & \\
\hline & Hayır & 242 & 51 & 232 & 49 & $7.313 *$ \\
\hline \multirow[t]{2}{*}{ Aile Dışında Şiddet } & Evet & 13 & 20.3 & 51 & 79.7 & $25.909 * * *$ \\
\hline & Hayır & 240 & 53.6 & 208 & 46.4 & \\
\hline \multirow[t]{2}{*}{ Ailede Ergene Şiddet } & Evet & 10 & 26.3 & 28 & 73.7 & $9.269 * *$ \\
\hline & Hayır & 243 & 51.3 & 231 & 48.7 & \\
\hline \multirow[t]{2}{*}{ Ailede Alkol } & Evet & 41 & 36.9 & 70 & 63.1 & $9.238 * *$ \\
\hline & Hayır & 212 & 52.9 & 189 & 47.1 & \\
\hline \multirow[t]{2}{*}{ Ailede Cezaevi. } & Evet & 7 & 21.2 & 26 & 78.8 & $10.917 * *$ \\
\hline & Hayır & 246 & 51.4 & 233 & 48.6 & \\
\hline
\end{tabular}

Tablo 3'ten izleneceği gibi, annenin gelir getirici bir işte çalışıp çalışmadığına göre şiddet eğiliminin yaygınlığı incelendiğinde, yüksek şiddet eğilimi olan ergenlerin \%51.5'inin $(n=70)$ annesinin gelir getirici bir işte çalıştığı, \%50.2' $\operatorname{sinin}(n=189)$ annesinin gelir getirici bir işte çalışmadığı gözlenmektedir. Gruplara ilişkin gözlenen yüzdeler arasındaki fark manidar bulunmamıştır. $\left(\mathrm{X}^{2}=.528 ; \mathrm{p}>.05\right)$. Babanın gelir getirici bir işte çalışıp çalışmadığına göre şiddet eğiliminin yaygınlığı incelendiğinde, yüksek şiddet eğilimi olan ergenlerin \%52.5'inin $(n=229)$ babasının gelir getirici bir işte çalıştığı, \%39.5'inin (n=30) babasının gelir getirici bir işte çalışmadığı gözlenmektedir. Gruplara ilişkin gözlenen yüzdeler arasındaki fark manidar bulunmuştur. $\left(\mathrm{X}^{2}=6.319\right.$; $\mathrm{p}<.05)$.

Aile bireylerinin birbirlerine şiddet uygulayıp uygulamadığına göre şiddet eğiliminin yaygınlığı incelendiğinde, yüksek şiddet eğilimi olan ergenlerin \%71'inin $(\mathrm{n}=27)$ aile bireylerinin birbirine şiddet uyguladığı, \%49'unun $(\mathrm{n}=232)$ aile bireylerinin birbirine şiddet uygulamadığı gözlenmektedir. Gruplara ilişkin gözlenen yüzdeler arasındaki fark manidar bulunmuştur. $\left(\mathrm{X}^{2}=10.917\right.$; $\left.\mathrm{p}<.05\right)$. Aile dışında birinin şiddet uygulayıp uygulamadığına göre şiddet eğiliminin yaygınlığı incelendiğinde, yüksek şiddet eğilimi olan ergenlerin \%79.7'sine $(n=51)$ aile dışında birinin şiddet uyguladığ \%46.4'üne $(n=208)$ aile dışında birinin şiddet uygulamadığı gözlenmektedir. Gruplara 
ilişkin gözlenen yüzdeler arasındaki fark manidar bulunmuştur. $\left(X^{2}=25.909 ; p<.001\right)$. Aile bireylerinin ergenin kendisine şiddet uygulayıp uygulamadığına göre şiddet eğiliminin yaygınlığı incelendiğinde, yüksek şiddet eğilimi olan ergenlerin \%73.7'sine $(\mathrm{n}=28)$ aile bireylerinin şiddet uyguladığı, \% 48.7'sine $(\mathrm{n}=231)$ aile bireylerinin şiddet uygulamadığı gözlenmektedir. Gruplara ilişkin gözlenen yüzdeler arasındaki fark manidar bulunmuştur. $\left(X^{2}=9.269 ; \mathrm{p}<.01\right)$.

Ailede alkol kullanan bulunup bulunmadığına göre şiddet eğiliminin yaygınlığı incelendiğinde, yüksek şiddet eğilimi olan ergenlerin \%63.1'inin ( $n=70)$ ailesinde alkol kullanan bireylerin bulunduğu, \%47.1'inin (n=189) ailesinde alkol kullanan bireylerin bulunmadığı gözlenmektedir. Gruplara ilişsin gözlenen yüzdeler arasındaki fark manidar bulunmuştur. $\left(\mathrm{X}^{2}=9.238 ; \mathrm{p}<.01\right)$. Ailede cezaevinde kalmış/ kalmakta olan bulunup bulunmadığına göre şiddet eğiliminin yaygınlığı incelendiğinde, yüksek şiddet eğilimi olan ergenlerin \%78.8'inin $(n=26)$ ailesinde cezaevinde kalmış/ kalmakta olan birinin bulunduğu, \%48.6'sının $(\mathrm{n}=233)$ ailesinde cezaevinde kalmış/ kalmakta olan birinin bulunmadığı gözlenmektedir. Gruplara ilişkin gözlenen yüzdeler arasındaki fark manidar bulunmuştur. $\left(X^{2}=10.917 ; \mathrm{p}<.01\right)$.

\section{Sonuç ve Tartışma}

Ergenlerde şiddet eğiliminin görülme sıklı̆̆ının bireysel ve ailesel niteliklere göre incelendiği bu araştırmada, bireysel nitelikler açısından; erkek ergenler arasında, akademik başarısı düşük olan ergenler arasında, şiddet ve kahramanlık filmleri izleyen ergenler arasında şiddet eğiliminin daha sık görüldüğü ortaya çıkmıştır. Ortaya çıkan bu sonuçlar literatürde yer alan araştırma sonuçları ile tutarlı görülmektedir.

Şiddet eğiliminin erkek ergenler arasında daha sık görüldüğünü gösteren yurtdış1 araştırmalar (Giles \& Heyman, 2005; Gullone \& Moore, 2000; Scharf, 2000) bulunmaktadır. Lopez ve Emmer'ın (2002) erkek ergenler üzerinde yaptığı çalışmaya göre, hem fiziksel savunma içeren kavgalarda hem de çetelerden kaynaklanan suçlarda, "erkeklik" anlayışının şiddeti tetiklediği görülmektedir. Thomas ve Smith de (2004), erkek öğrencilerin kız öğrencilere göre, öfkelendiklerinde şiddete daha eğilimli ve provokasyonlara daha açık olduklarını bulgulamışlardır. Ülkemizde liseler üzerinde gerçekleştirilen farklı araştırmalarda da erkek öğrencilerin saldırganlık ve şiddet düzeylerinin kız öğrencilere göre daha yüksek olduğu bulunmuştur (Durmuş ve Gürgan, 2003; Efilti, 2006; Karakaya, 2008; Tuzgöl, 2000). Şiddete başvurma kadar şiddetten kaçınma davranışı da araştırmalara konu olmuştur. 11-20 yaş arasındaki öğrencilerde sosyal eğilimlerin belirlenmesine yönelik bir araştırmada kız öğrencilerin şiddetten kaçınma eğilimleri erkek öğrencilere kıyasla daha yüksek bulunmuştur (Tekin, Özkara, Cebeci ve diğerleri, 2007). Elbette bu durumun toplumsal yapımızla yakından ilişkisi vardır. $\mathrm{Bu}$ durum toplum olarak kadın ve erkeklere yüklenen rollerle yakından ilişkili görülmektedir. Toplumsal araştırma ve gözlemler dikkate alındığında, kız ergenlerin uyumlu davranma konusunda daha fazla baskı hissettikleri ve öfkelerini ifade etmekten kaçındıkları; erkek ergenlerinse öfkelerini ifade etme konusunda daha çok onay gördükleri anlaşılmaktadır. Bilge'nin (2006) belirttiği gibi toplumumuzda kadınlar öfkelerini pasif- agresif bir şekilde yaşarken, erkekler şiddete dönüştürebilmektedir. 
Şiddetin akademik başarısı düşük olan ergenler arasında daha sık görüldüğü araştırma bulguları arasındadır. Düşük akademik başarı ile şiddet arasında bir ilişki olduğunu destekleyen farklı araştırmalar söz konusudur (Amerikan Psikoloji Derneği, 2002; Fager \& Boss, 1998; Ulusal Okul Güvenliği Merkezi, 2000). Akademik başarının düşüklüğünün, ilgili pek çok değişkenle bir araya gelerek ergeni olumsuz etkilediği düşünülebilir. Akademik başarısı düşük ergenler için anne babanın yeterli bir ilgi ve denetiminin olmayışı, başarısı düşük ergenlerin bu noktada yaşadıkları eksikliği ve arkadaşları arasında onaylanmayı şiddet gibi farklı yollarla sağlamaya çalışabilecekleri, okula ait olma ve akademik ilerleme beklentisi olmayan ergenlerin şiddet ve suça yönelen yapılara dahil olarak kimlik arayışına girmeleri gibi pek çok etken akla gelmektedir.

Şiddet eğilimi, şiddet filmleri ve kahramanlık filmleri izleyenler arasında daha sık görülmektedir. Ülkemizde farklı dönemlerde yayınlanmış olan Kurtlar Vadisi gibi pek çok dizide kahramanlıkla şiddetin iç içe sunulduğu ve özdeşleştirildiği görülmektedir. Giriş bölümünde ele alındığı gibi, medyanın şiddet eğilimi ve şiddet davranışı üzerinde, çocukluk döneminden başlayarak çok çeşitli etkileri söz konusudur. Medya, insanların şiddeti ve sapkınlığı değerlendirme biçimlerini de etkilemektedir. Televizyonların bazı yayınları, toplumun yarattığı iyi ve kötü, açık ve özel, utanma ve onur arasındaki sınırları yok edici niteliktedir. Bu konuda vurgulanan en olumsuz etki, televizyon başta olmak üzere tüm medya araçlarının şiddeti "normal" olarak tanımlamaları ve göstermeleridir. Öldürme bile bazen anlaşılabilir olarak gösterilebilmektedir (Johnson \& Johnson, 1995).

Şiddet eğiliminin görülme sıklığı ailesel nitelikler açısından incelendiğinde, ailesinde şiddet uygulanan, ailede ve aile dişında şiddete maruz kalan, ailesinde cezaevinde kalmış/ kalmakta olanların ve alkol kullananların olduğu ergenler arasında şiddet eğilimi daha sık görülmektedir. Babası gelir getiren bir işte çalışan ergenler arasında şiddet eğilimi daha sık görülmekteyken; annesi gelir getiren bir işte çalışan ve çalışmayan ergenler arasında manidar bir fark olmadığı görülmüştür. Karakaya'nın (2008) İstanbul ili Endüstri Meslek liseleri öğrencilerinin şiddet eğilimlerini incelediği araştırmada da, öğrenci babalarının iş durumunun, onların açık ve örtülü şiddet boyutunu değerlendirmelerinde anlamlı bir farklılaşmaya neden olduğu görülmüştür. Babası çalışmayan öğrencilerin diğer iki gruptaki öğrencilere göre açık ve örtülü şiddet boyutunu daha fazla benimsedikleri görülmüştür. Kentlerde özellikle babanın çalışmak zorunda olmasının, ailenin çocuk üzerindeki denetiminin zayıflamasına yol açtığı, böylece çocukların olumsuz modelleri örnek almalarına ve suça eğilimli grupların içine girmelerine kolaylık sağlayabildiği düşünülmektedir (Turan \& Beşirli, 2008).

Ailesinde ergenin kendisine veya diğer aile üyelerine şiddet uygulanan ergenler arasında şiddet eğilimi daha sık görülmektedir. Bu bulgu şiddetle ilgili pek çok farklı araştırmada da görülmektedir. Kitzmann, Gaylort, Holt ve Kenny (2003) aile içi şiddete tanık olan çocuklarda meydana gelen psiko-sosyal sonuçları ele aldıkları, 1978- 2000 yılları arasındaki 118 araştırmayı inceledikleri meta analitik çalışmalarında, şiddete tanık olan çocukların şiddete tanık olmayanlardan daha fazla olumsuz davranışlar 
sergilediklerini gözlemlemişlerdir. Benzer araştırma sonuçları ülkemizde Özcebe'nin (2006) ergen öğrenciler üzerinde yaptığı araştırmada da görülmektedir. Evde şiddete maruz kalma ya da bir başkasının şiddete maruz kalması da ergenlerin şiddete yönelmelerinde önemli nedenler arasında yer almaktadır. Krug ve diğerlerine (2002) göre aile yaşamında şiddeti problem çözmenin bir yolu olarak öğrenen bireyler şiddet uygulamaya eğilimlidirler. Çocukluk ve ergenlik dönemlerinde, aile içi şiddetin uygulandığı bir ortamda yetişen bireylerin, şiddet gösterme eğilimine sahip oldukları pek çok farklı araştırmada belirtilmektedir. Ayrıca şiddetin, toplum tarafından paylaşılan bir değer yargısı olarak kabul edilmesi ve kuşaktan kuşağa aktarılarak bazı kültürlerce desteklenmesi de sosyal bir neden olarak kabul edilmektedir (Rynerson, 1997).

Araştırmanın diğer bulgularına göre, ailesinde alkol kullananların bulunduğu ve cezaevinde kalmış/kalmakta olan bireylerin olduğu ergenler arasında şiddet eğilimi daha sık görülmektedir. Ortaya çıkan bu sonuçlara farklı araştırmalarda da rastlanmaktadır. Alkol ve madde kullanımının olduğu ailelerde şiddet davranışının görülme sıklığının daha fazla olduğunu gösteren araştırmalar söz konusudur (ABD Okulda Şiddetin Kaynakları Merkezi, 2002; Brennan, Medrick \& Hodgins; 2000; Kızmaz, 2006; Özcebe, 2006; Renzetti \& Edleson, 2008). Ailelerinde suç işleyen bireylerin olduğu ergenlerin şiddete ve suça eğilimlerini gösteren araştırmalar da bulunmaktadır (Avcı, 2006; Hüsman, 2007; Karakaya, 2008) Yapılan pek çok çalışmada, ailenin suça ve şiddete yönelik geçmişi ailesel risk faktörleri arasında yer almaktadır (ABD Okulda Şiddetin Kaynakları Merkezi, 2002; Herrenkohl, Farrington ve diğerleri, 2000). Suça eğilimli ya da suç işlemiş bireylerin çocukları için kendi adaletini oluşturma gibi yöntemleri benimseme söz konusu olabilmektedir. Toplumda hak arama veya namusunu temizleme gibi sebeplerle şiddete başvurmanın haklılık gerekçesi haline getirilmesi, ergenlere olumsuz model olan tutum ve davranışları benimsemelerine yol açabilmektedir.

Elbette ergenler şiddet ile sadece aile içinde karşılaşmamaktadır. Ergenin önemli bir zaman dilimini geçirdiği okulda bulunan kimseler, okuldan eve dönene kadar karşılaştığı bireyler, arkadaşları, komşuları, sosyal çevresinde bulunan kimseler de ergenin yaşamında önemli bir role sahip olabilmektedir. Ergenlerin pek çok durumda şiddet yaşantılarını ailelerinden veya yakınlarından saklayabildikleri bilinmektedir. Dolayısıyla ergenin çevresinden gördüğü ve başkalarına ifade etmediği şiddetin, ergenin öfke duygusunu artırarak şiddet eğilimini etkilediği düşünülebilir. Ayrıca, ergenler model alma yoluyla kendilerine şiddet uygulayan bireylerin şiddet davranışlarını model alabilir veya bu davranışları haklı bulma yolunda düşünceler geliştiren ergenin şiddet eğilimi artabilir.

\section{Öneriler}

Ergenlerin şiddete eğilim göstermelerinde etkili olan etmenlerin belirlenerek şiddet eğiliminin önlenmesine yönelik farklı çalışmalara ihtiyaç duyulduğu açıktır. Öfke kontrolüne yönelik etkili bulunmuş deneysel çalışmalar olmakla birlikte (Akdeniz, 2007; Bilge, 1997; Duran \& Eldeleklioğlu, 2005; Gebeş, 2011; Gültekin, 2011; Kellner \& Bry, 1999; Özmen, 2006) şiddet eğilimini etkileyen farklı değişkenleri dikkate alan 
çalışmaların da yapılmasında fayda görülmektedir. Okul psikolojik danışmanlarının öğrencilere ve velilere yönelik deneysel çalışmaları uygulamaları, öfke kontrolü seminerleri düzenlemeleri; okul yönetiminin okulda şiddetsiz bir ortam için gerekli önlemleri almaları gerekmektedir. Şiddeti önlemeye yönelik çalışmalar erken yaşlardan başlayarak, okul temelli olarak düzenlenebilir. Okul müfredatlarına şiddeti önlemeye yönelik eğitsel müdahaleler eklenebilir. Şiddetle ilgili diğer çalışmalarda da görüldüğü gibi, şiddetsizliğin bir değer olarak benimsenmesi için toplumca mücadele edilmelidir. 


\section{Kaynakça}

Akdeniz, M. (2007). Öfke Kontrolü Ĕ̈itiminin Lise Öğrencilerinin Öfke Kontrolü Becerilerine Etkisi (Yayınlanmamış Yüksek Lisans Tezi). Çukurova Üniversitesi/ Sosyal Bilimler Enstitüsü, Adana.

American Psychological Association (2002). Warning Signs. [Available online at: http://helping.apa.org/warningsigns] Erişim tarihi: 01.05.2007.

Atkinson, R.L., \& Atkinson, R.C. (2008). Psikolojiye Giriş. (Çev: K. Atakay, M. Atakay). Ankara: Arkadaş.

Avc1, R. (2006). Şiddet Davranışı Gösteren ve Göstermeyen Ergenlerin Ailelerinin Aile İslevleri, Öfke ve Öfke Ifade Tarzları Açısından Incelenmesi (Yayımlanmamış yüksek lisans tezi). Çukurova Üniversitesi/ Sosyal Bilimler Enstitüsü, Adana.

Bilge, F. (1997). Danışandan Hız Alan ve Bilişsel Davranışçı Yaklaşımlarla Yapılan Grupla Psikolojik Danışmanın Üniversite Öğrencilerinin Kızgınlık Düzeyleri Üzerindeki Etkileri. Türk Psikolojik Danışma ve Rehberlik Dergisi, 2 (8): 9-16.

Bilge, F. (2006). Ergenlerin Öfkeyle Baş Etmelerine Nasıl Yardımcı Olabiliriz? Çocuk ve Ergene Yönelik Şiddetin Önlenmesi Sempozyumu, 15-16 Mayıs. Ankara.

Blaser, T. (2008). SAIRR Today: Violence In Schools. [Available online at South African Institute of Race Relations: http://www.sairr.org.za/sairr-today/sairr-todayviolence-in-schools-15-august-2008.html/?searchterm=violence] Erişim tarihi: 30.12.2012.

Brennan, P.A., Medrick S.A., \& Hodgins S. (2000). Major Mental Disorder and Criminal Violence in a Danish Birth Cohort. Archive of General Psychiatry, 57, 494-500.

Burton, P. (2008). Merchants, Skollies and Stones: Experiences of School Violence in South Africa (Monograph No. 4). Cape Town: Centre for Justice and Crime Prevention.

Çuhadaroğlu, F. (2006). Şiddetin Psikolojik Boyutu: Gençlik Ve Şiddet Araştırmalart. Çocuk ve Ergene Yönelik Şiddetin Önlenmesi Sempozyumu, 15-16 Mayıs. Ankara.

Debarbieux, E. (2009). Okulda Şiddet, Küresel Bir Tehdit. (Çev: İsmail Yerguz) İstanbul: İletişim.

Duran, Ö.,\& Eldeleklioğlu, J. (2005). Öfke Kontrol Programının 15-18 Yaş Arası Ergenler Üzerindeki Etkililiğinin Araştırılması. G. Ü. Gazi Eğitim Fakültesi Dergisi, 25 (3): 267- 280.

Durmuş, E. \& Gürgan, U. (2003). Lise Öğrencilerinin Şiddet ve Saldırganlık Eğilimleri. VII. Ulusal Psikolojik Danışma ve Rehberlik Kongresi, 9-11 Temmuz, İnönü Üniversitesi, Malatya.

Efilti, E. (2006). Orta Öğretim Kurumlarında Okuyan Öğrencilerin Saldırganlık ve Denetim Odă̆ı ve Kişilik Özelliklerinin Karşılaştırmalı Olarak Incelenmesi. 
(Yayımlanmamış yüksek lisans tezi). Selçuk Üniversitesi/ Sosyal Bilimler Enstitüsü, Konya.

Fager, J. S. \& Boss, S. (1998). Peaceful Schools. United States: Northwest Regional Educational Laboratory.

Gebeş, H. (2011). Akran Ĕgitimi ile Desteklenen Öfke Kontrolü Ĕgitiminin Lise Öğrencilerinin Öfke Kontrol Becerilerine Etkisi. (Yayımlanmamış yüksek lisans tezi). Çukurova Üniversitesi/ Sosyal Bilimler Enstitüsü, Adana.

Giles, J.W., \& Heyman, G.D. (2005). Preschoolers' Use of Trait-Relevant Information to Evaluate The Appropriateness of an Aggressive Response. Aggressive Behavior, 31, 498-509.

Gittins, C. (Ed.). (2005). Okullarda şiddetin azaltılması. Avrupa Konseyi El kitabı.

Gullane, E., \& Moore, S. (2000), Adolescent risk taking and 5 factor model of personality. Journal of Adolescence, 23 (4), 393-407.

Gültekin, F. (2011). İlköğretim Ikinci Kademe Öğrencilerinin Öfke ve Saldırganlık Düzeylerinin Azaltılması. Hacettepe Üniversitesi Ĕ̆itim Fakültesi Dergisi, 41, 180-191.

Gümüş, A. (2006). Şiddetin Nedenleri. Toplumsal Bir Sorun Olarak Şiddet Sempozyumu, 20- 21 Mayıs, Ankara.

Haskan, Ö. \& Yıldırım, İ. (2012). Şiddet Eğilimi Ölçeği’nin Geliştirilmesi. Eğitim ve Bilim, 37 (163), 165-177.

Heitmeyer, M., \& Hagan, J. (2005). International Handbook of Violence Research. USA: Kluwer Academic.

Hüsman, Z. (2007). Lise İkinci Sinıf Öğrencilerinin Şiddet Deneyimlerinin Nitelik ve Nicelik Açısından Tetkiki. (Yayımlanmamış yüksek lisans tezi). Maltepe Üniversitesi/ Sosyal Bilimler Enstitüsü, İstanbul.

İnanç, B.Y., Bilgin, M., \& Atıcı, M.K. (2005). Gelişim Psikolojisi: Çocuk ve ergen gelişimi. Adana: Nobel.

İpek, C. (2007). Okullarda şiddet bağlamında ilköğretim programına konan medya okur-yazarlığı dersi. A. Solak (Ed.) Okullarda şiddet ve çocuk suçluluğu içinde (s. 235-262). Ankara: Pegem.

Johnson, D.W., \& Johnson, R.T. (1995). Reducing School Violence Through Conflict Resolution. Retrieved from: http://books.google.com/books

Karakaya, E. (2008). Endüstri Meslek Lisesi Öğrencilerinin Şiddet Eğilimlerinin Çok Yönlü Olarak Değerlendirilmesi, Ístanbul Ili Avrupa Yakası Örneği. (Yayımlanmamış yüksek lisans tezi). Yeditepe Üniversitesi/ Sosyal Bilimler Enstitüsü, İstanbul.

Kellner, M. H.,\& Bry, B. H. (1999). The Effects of Anger Management Groups in a Day School for Emotionally Disturbed Adolescents. Adolescence, 34 (136), 645651. 
Kitzmann, K. M., Gaylord, N. K., Holt, A. R., \& Kenny, E. D. (2003). Child Witnesses to Domestic Violence: A Meta-Analytic Review. Journal of Consulting and Clinical Psychology, 71 (2), 339-352.

Kızmaz, Z. (2006). Okullardaki Şiddet Davranışının Kaynakları Üzerine Kuramsal Bir Yaklaşım. Ç.Ü. Sosyal Bilimler Dergisi, 30 (1), 47-70.

Krug E.G., Dahlberg, L.L., Mercy, J.A., Zwi, A.B., \& Lozano, R. (Eds.) (2002). World Report on Violence and Health. WHO: Geneva, Switzerland.

Lopez, V.A., \& Emmer, E.T. (2002). Influences of Beliefs and Values on Male Adolescents' Decisions to Commit Violent Offenses. Psychology of Men and Masculinity, 3, 28-40.

Özcebe, H. (2006). Adölesanlar ve Şiddet. Çocuk ve Ergene Yönelik Şiddetin Önlenmesi Sempozyumu. 15-16 Mayıs. Ankara.

Özmen, A. (2006). Öfkeyle Başa Çıkma Eğitiminin ve Etkileşim Grubu Uygulamasının İçe Yönelik Öfke Üzerindeki Etkisi. Ç.Ü. Sosyal Bilimler Dergisi, 30 (2): 175-185.

Renzetti, C.M., \& Edleson, J.L. (Ed.). (2008). Encyclopedia of Interpersonal Violence. UK.: Sage Publication

Rynerson, B. C. (1997) Violence Aganist Women, Maternity and Women's Health Care, (D.L. Lowdermilk et al.,Eds), Sixth Edition, St.Louis, Wiesbaden: Mosby Year Book.

Scharf, S. (2000). Genders Differences in Adolescent Aggression: An Analysis of Instrumentally. (Unpublished doctoral dissertation). Central Michigan University, UK.

TBMM Araştırma Komisyonu (2007). Çocuklarda Ve Gençlerde Artan Şiddet Eğilimi Ile Okullarda Meydana Gelen Olayların Araştırllarak Alınmasi Gereken Önlemlerin Belirlenmesi Amacryla Kurulan (10/337,343,356,357) Esas Numaralı Meclis Araştırma Komisyon Raporu. Ankara: MEB Özel Eğitim Rehberlik ve Danışma Hizmetleri Genel Müdürlüğü.

Tekin, O., Özkara, A., Cebeci, S., Işık, B., Çatal, F., Doğan, D.G., Bilici, M., \& Kara, S. (2007). 11-20 Yaş Öğrencilerde Sosyal Eğilimler Anketi: 308 Öğrenci Üzerinde Pilot Çalışma. Yeni Tıp Dergisi, 24 (4), 198-204.

Thomas, S. P., \& Smith, H. (2004). School Connectedness, Anger Behaviors, and Relationships of Violent and Nonviolent American Youth. Perspectives in Psychiatric Care, 40 (4), 135-138.

Turan, M. T., \& Beşirli, A. (2008). Kentleşme Sürecinin Ruh Sağlı̆ğ Üzerine Etkileri. Anadolu Psikiyatri Dergisi, 9, 238-243.

Tuzgöl, M. (2000). Ana-Baba Tutumları Farklı Lise Öğrencilerinin Saldırganlık Düzeylerinin Çeşitli Değişkenler Açısından İncelenmesi. Türk Psikolojik Danışma ve Rehberlik Dergisi, 2 (14), 39 - 48. 
Unnever, J. D., Cullen, F. T., \& Agnew, R. (2006). Why Is 'Bad' Parenting Criminogenic?: Implications from Rival Theories. Youth Violence and Juvenile Justice, 4 (1), 3-33.

USA School Violence Resource Center. (2002). National Center for Rural Law Enforcement - Criminal Justice Institute. University of Arkansas: Little Rock, AR. 